Original article

\title{
PROGNOSTIC FACTORS AFFECTING SURVIVAL OF PATIENTS AFTER LIVER RESECTION DUE TO COLORECTAL LIVER METASTASES
}

\section{ПРОГНОСТИЧКИ ФАКТОРИ КОИ ШТО ВЛИЈААТ НА ПРЕЖИВУВАњЕТО НА ПАЦИЕНТИ ПОСЛЕ РЕСЕКЦИЈА НА ЦРНИОТ ДРОБ ПОРАДИ КОЛОРЕКТАЛНИ МЕТАСТАЗИ}

\author{
Stefan Petrovski ${ }^{1}$, Elena Arabadzhieva ${ }^{2}$, Saso Bonev ${ }^{2}$, Dimitar Bulanov ${ }^{2}$, Valentin Popov ${ }^{2}$ and \\ Violeta Dimitrova $^{2}$ \\ ${ }^{1}$ Department of Surgery-Clinical Hospital Shtip, PhD candidate at the Department of General and Hepato- \\ pancreatic Surgery, University Hospital "Aleksandrovska"-Sofia, Medical University-Sofia, ${ }^{2}$ Clinic of \\ General and Hepato-pancreatic Surgery, University Hospital "Aleksandrovska"-Sofia, Medical University- \\ Sofia, Bulgaria
}

\section{Apstract}

Introduction. Colorectal liver metastases have a poor prognosis and only $2 \%$ have an average 5 -year survival if left untreated. In recent decades there has been a development in the diagnosis, treatment and palliative treatment of patients with colorectal liver metastases, and despite radical resection the average five-year survival is between $25 \%$ and $44 \%$.

Aim. To explore the experience of the Clinic in the treatment of colorectal liver metastases, comparing it with data from the literature and based on the comparison to determine the prognostic factors that affect survival after radical surgical treatment of patients.

Methods. A retrospective study was conducted at the Clinic of General and Hepato-pancreatic Surgery at the University Hospital "Aleksandrovska"-Sofia. The study comprised the period between 01.01.2006 to 31.12.2015. It included a total of 239 cases, of whom: 179 patients underwent radical interventions, 5 palliative and 55 patients underwent explorative interventions due to liver metastases. Clinical and pathological materials were analyzed using SPSS-19 to determine the prognostic significance of a number of factors in relation to the survival: gender, age, type and localization of metastases, postoperative stage of the primary tumor, type and volume of liver resection, extrahepatic metastases, preoperative values of CEA, postoperative values (AST, ALT).

Results. Factors that correlated with lower survival type: metastases (synchronous or metachronus), localization of metastases (uni-or bilobar), presence of the regional lymph node metastases and metastases to other distant organs and the impossibility of radical resection of liver were statistically significant with multivariant analysis. Elevated preoperative value of CEA, the value of

Correspondence to: Stefan Petrovski, Department of Surgery at Clinical Hospital-Shtip, R. Macedonia; E-mail: stefan.petrovski@ugd.edu.mk hemoglobin and stage IV disease also affected the survival of patients.

Conclusion. In patients with colorectal liver metastases only resection has potentially curative character. The surgical strategy for resection in context of increasing the percentage of patients with resectable potential is the only possible factor for long-term survival.

Keywords: colorectal metastases, radical resections, prognostic factors, survival, stage of the disease

\section{Апстракт}

Вовед. Колоректалните метастази на црниот дроб имаат лоша прогноза и само $2 \%$ имаат средно 5-годишно преживување ако не се лекуваат. Во последните неколку декади се забележа развој во дијагностицирањето, лекувањето и палијацијата на пациенти со колоректални метастази на црниот дроб, но и покрај радикалната ресекција средното петгодишно преживување е помеѓу 25\% и 44\% .

Цел. Да се проучи искуството на Клиниката во лекувањето на колоректални метастази на црниот дроб, споредувајќи ги со податоците од светската литература, и врз основа на тоа да се определат прогностичките фактори кои што влијаат на преживувањето после радикално хирушко лекување на пациентите. Методи. Во клиниката по општа и црнодробнопанкреатична хирургија во УМБАЛ "Александровска"-Софија е направено ретроспективно проучување помеѓу 01.01. 2006 до 31.12.2015, вклучувајќи 239 случаи претставени во Табела 1, подложени соодветно на 179 радикални интервенции, 5 палијативни и 55 експлоративни по повод колоректални метастази на црниот дроб. Клиничкопатолошкиот материјал се анализираше со помош на SPSS-19, за да се определи прогностичката значајност во однос 
на преживувањето на редица фактори: пол, возраст, тип и локализација на метастазите, постоперативен стадиум на примарниот тумор, тип и обем на ресекцијата на црниот дроб, екстрахепатални метастази, предоперативни вредности на СЕА, постоперативни вредности на (AST, ALT).

Резултати. Фактори кои што корелираат со пониско преживување се типот на метастазите (синхрони или метахрони), локализацијата (уни- или билобарни), присусвото на метастази во регионалните лимфни жлезди и во други далечни органи како и неможноста за радикална ресекција на црниот дроб се статистички значајни со мултиваријантната анализа. Покачени предоперативни вредности на CEA, вредноста на Hgb и IV стадиум на болеста исто така имаат влијание на преживувањето на пациентите. Заклучок. Кај пацинетите со колоректални метастази на црниот дроб само ресекцијата има потенцијално лечебен карактер. Хирушката стратегија за ресекција во контекст на зголемувањето на процентот на пациенти кои имаат ресектабилен потенцијал е единствен можен фактор за долгогодишно преживување.

Клучни зборови: колоректални метастази, радикални ресекции, прогностички фактори, преживување, стадиум на болеста

\section{Introduction}

Colorectal cancer CRC is the third most common cancer worldwide after lung cancer and breast cancer $[1,2]$. A large percentage of $50-70 \%$ of patients develops colorectal liver metastases (CRLM) because of hematogenous dissemination of primary cancer [3-7]. Synchronous metastases are diagnosed in 15-25\% [8-10] during the primary diagnosis of CRC and in $20-25 \%$ [11-15] in the first five years metachronous metastases develop. They represent the most common cause of death caused, so that $77 \%$ of untreated patients die in the first year, and only $14-23 \%$ survive more than three years [16-19]. Surgical resection represents the only curative treatment approach to patients with CRLM; in larger series patients treated with resection have a mean 5-year survival from $25 \%$ to $44 \%$ [15,20,21], but only $15-25 \%$ [22] of metastasis of liver are initially resectable. Poor prognosis of the disease is the cause of looking for opportunities to improve postoperative results which corresponds with defining determinants of survival.

Aim. To explore the experience of the Clinic in the treatment of colorectal liver metastases, comparing them with data from the literature, and based on the comparison to determine the prognostic factors that affect survival after radical surgical treatment of patients.

\section{Methods and materials}

A retrospective study was conducted at the Clinic of General and Hepato-pancreatic surgery at the University Hospital "Aleksandrovska"-Sofia. The study comprised the period between 01.01.2006 to 31.12.2015. It included a total of 239 patients (Table 1), of whom: 179 patients underwent radical interventions, 5 palliative and 55 patients underwent explorative interventions due to liver metastases. In addition, 119(49.8\%) patients were diagnosed with synchronous metastases, $120(50.2 \%)$ patients with metachronous metastases, including 7(2.9\%) with metachronous metastases with recurrence on the colon. With regard to sex structure of the patients there were 93(38.91\%) women and 146(61.08\%) men. Majority of patients were aged 61 to 70 years-88(36.82\%), while a small percent belonged to the youngest age group under 40 years- $9(3.77 \%)$.

Table 1. Types of radical and palliative surgical interventions used for resections of patients with colorectal liver metastases, included in our study

\begin{tabular}{|c|c|c|c|}
\hline \multicolumn{4}{|c|}{$\begin{array}{r}\text { Type of operation } \\
\end{array}$} \\
\hline $\begin{array}{c}\text { Radical } \\
\mathrm{N}=179(\mathbf{7 4 . 9 \% )}\end{array}$ & & $\begin{array}{c}\text { Palliative / biops } \\
\mathrm{N}=60(25.1 \%)\end{array}$ & \\
\hline atypical resection & 57 & biopsy & 55 \\
\hline resection of 2 segments & 24 & biopsy+biliary drainage & 2 \\
\hline resection of 3 segments & 18 & thermoablation & 1 \\
\hline resection of $>3$ segments & 10 & alcoholization & 2 \\
\hline left lobectomy & 15 & & \\
\hline left hemihepatectomy & 4 & & \\
\hline right hemihepatectomy & 12 & & \\
\hline Metastasectomy & 20 & & \\
\hline resection+another procedure & 19 & & \\
\hline atypical resection+metastasectomy & 9 & & \\
\hline left lobectomy +atypical resection & 5 & & \\
\hline atypical resection+thermoablation & 4 & & \\
\hline atypical resection+alcoholization & 1 & & \\
\hline
\end{tabular}


The follow-up period of the patients operated on for colorectal liver metastases in the Clinic, was 5 years after resection of the liver according to the method of Kaplan-Mayer. Statistical analysis of the collected material to determine the factors for survival was done using SPSS-19, and it included sex, age, type and localization of metastases, postoperative stage of primary tumor, type and amount of resection of the liver, extrahepatic metastases, preoperative CEA values and postoperative values (AST, ALT).

\section{Results}

The cumulative overall survival is shown in Table 2, and it was $79.6 \%$ in the first year, $25.9 \%$ in the third year, and $19.2 \%$ in the fifth year.

Table 2. Cumulative survival of patients after radical resection of colorectal liver metastases

\begin{tabular}{lccc}
\hline & \multicolumn{2}{c}{$\begin{array}{c}\text { Cumulative survival } \\
\text { 1-year }\end{array}$} & $\begin{array}{c}\text { \%-year } \\
\text { ( Std.Error) }\end{array}$ \\
\hline $\begin{array}{l}\text { Total } \\
\text { survival }\end{array}$ & $80(0.029)$ & $25.9(0.03)$ & $19.2(0.025)$ \\
\hline
\end{tabular}

Survival Function

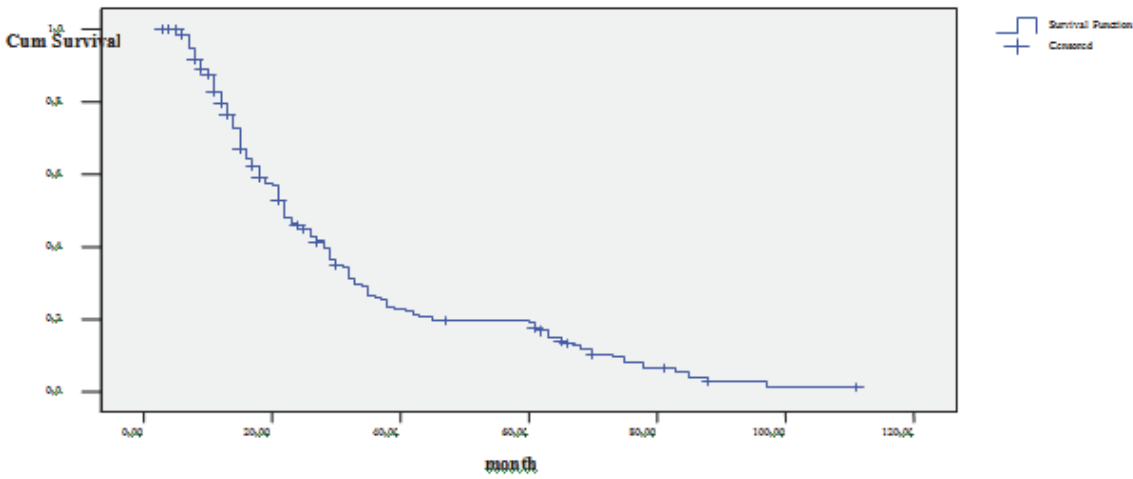

Fig. 1. Curve of survival in patients with colorectal cancer and liver metastases

Survival analysis by gender indicated that within the group of female patients 68 died $(81.93 \%)$, while in the male patients group death occurred in 101(80.8\%). The median survival for women with CRLM was 31.9 months and for men shorter-30.8 months. The median survival was 25 months in female patients with CRLM and 22 months in male patients. However, the results did not show statistical significance $(\mathrm{p}=0.69, \mathrm{p}=0.7)$.

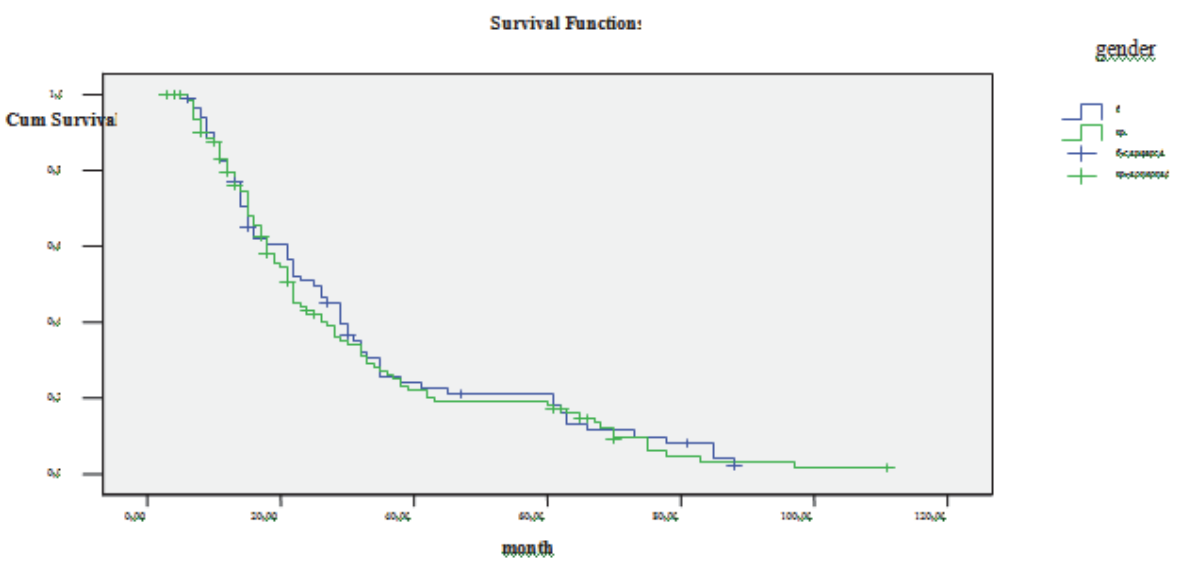

Fig. 2. Curve of survival according to sex of patients, Log Rank (Mantel-Cox) $p=0.69$ Breslow $p=0.7$

The analysis by age showed that the median survival was 34.3 months in patients under 40 years, 29.8 months in the age group 41-50 years, 29.2 months in patients aged 51 to 60 years, 34.1 months in patients aged 61 70 years and 29.2 months in patients over 70 years. However, these differences were not statistically significant (Figure 3). 


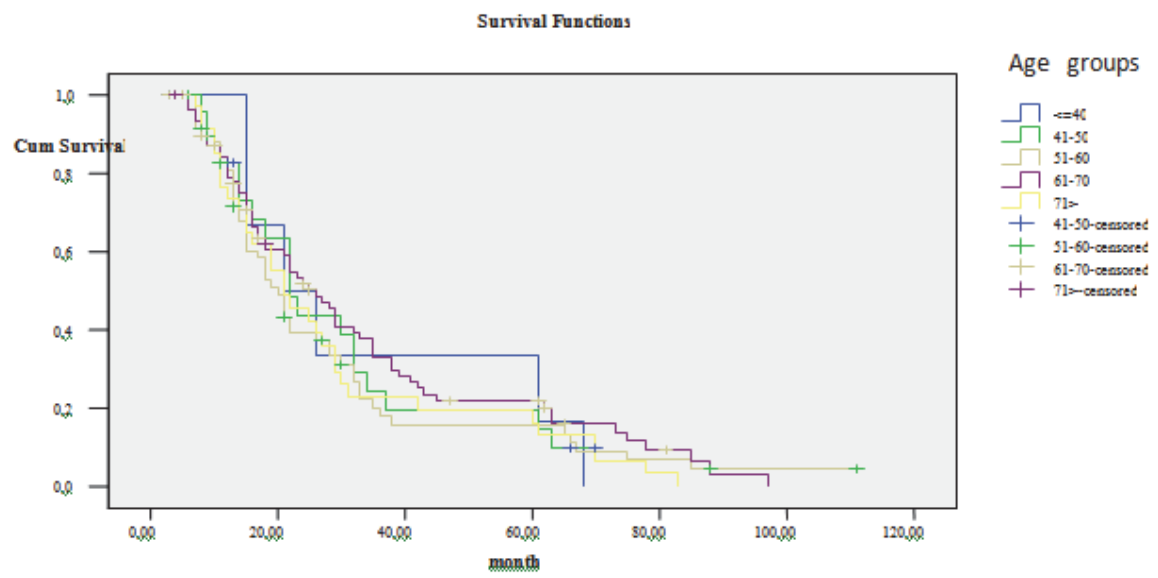

Fig. 3. Survival curves according to age, LogRank (Mantel-Cox) $p=0.78$ Breslow $p=0.74$

The analysis showed that the hazard ratio-Exp (B) for liver metastases was 1.49 95\% CI (1.098-2.022), $\mathrm{p}=0.01$. These factors suggest that the type of liver metastases in patients with colorectal cancer is a significant prognostic factor for survival. Statistical analysis showed that there was a significant difference in survival time depending on the type of liver metastases $(p=0.008$, $\mathrm{p}=0.002$ ). Patients with colorectal cancer and metachronous metastases had a significantly longer survival time.

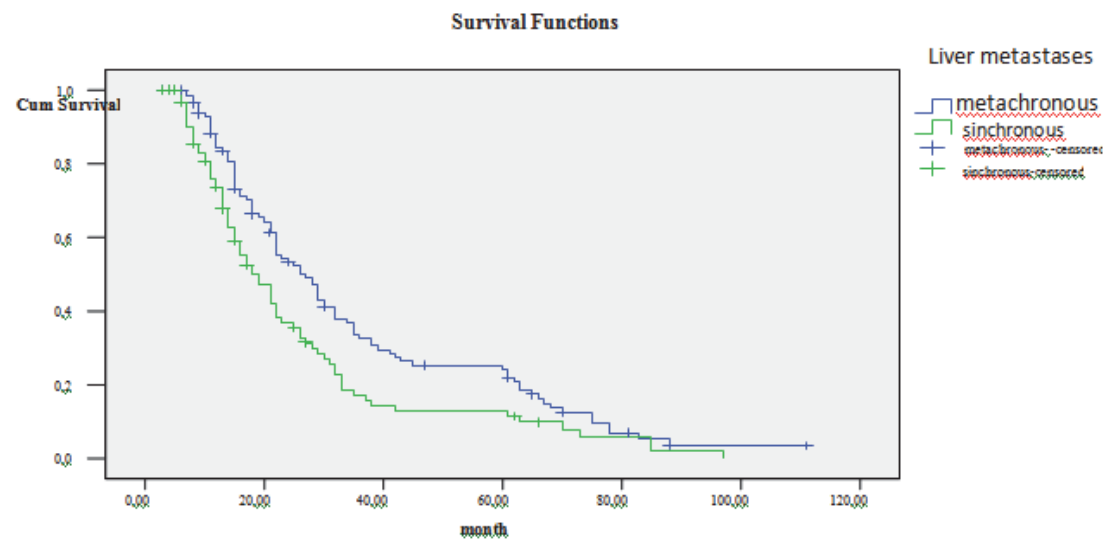

Fig. 4. Curve of survival depending on type of liver metastases

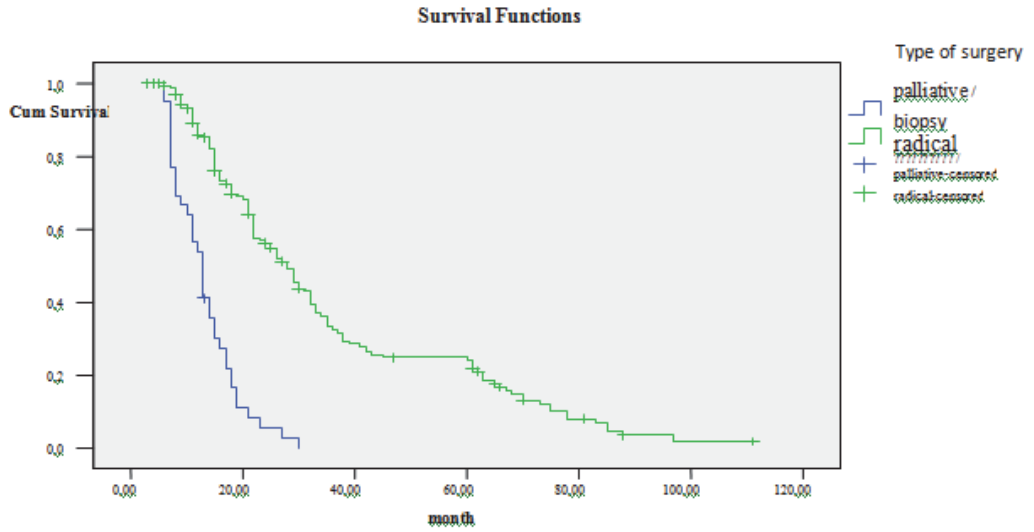

Fig. 5. Curves of survival depending on type of surgical resection

Radical intervention was also proved to be a significant factor for survival with Lesser Cox-regression analysis $(\mathrm{p}<0.0001)$.

The value of HP of $0.20395 \%$ CI (0.135 - 0.306) su- ggests that the risk of fatal outcome in patients treated with radical intervention was $79.7 \%$ lower than in patients treated palliative or with biopsy. 


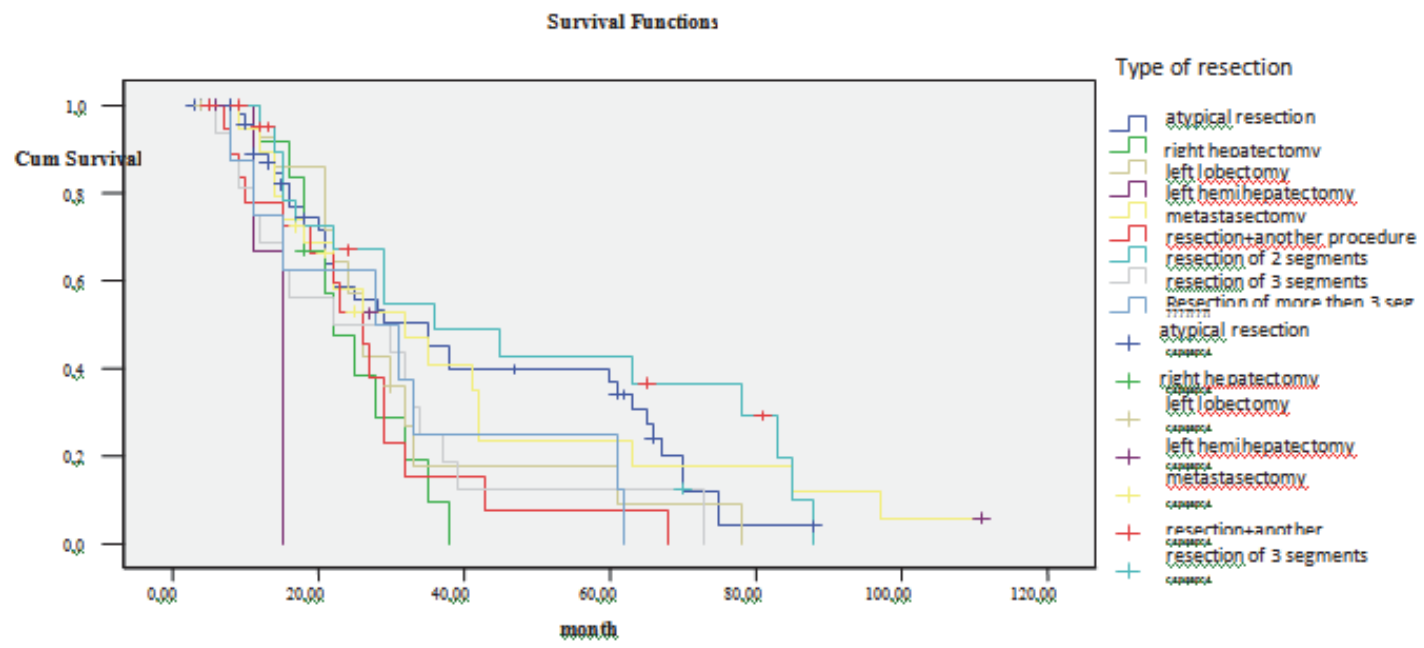

Fig. 6. Curves of survival depending on type of resection

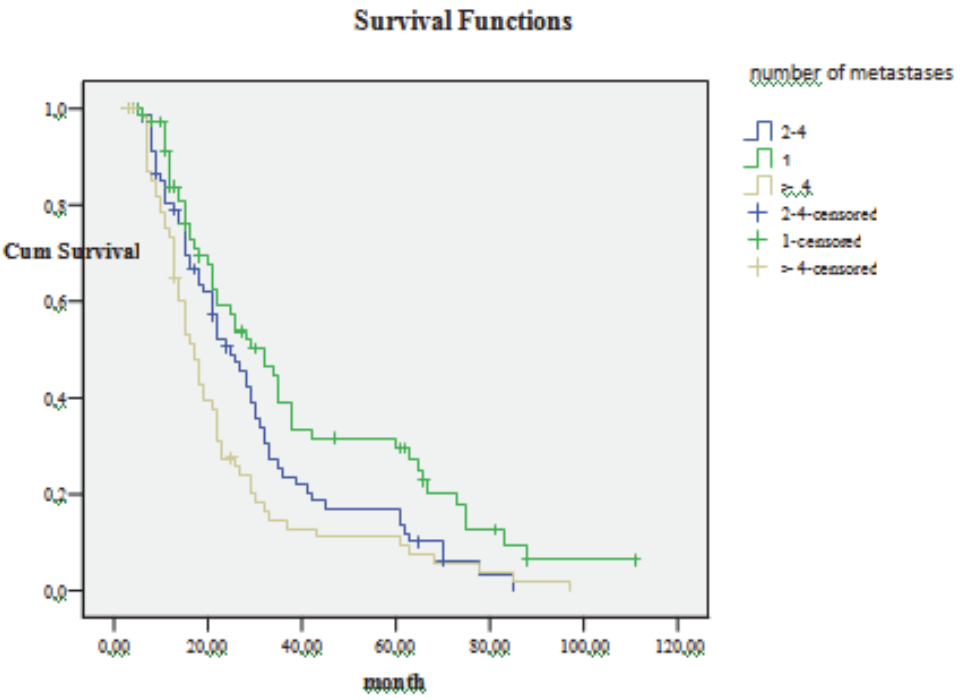

Fig. 7. Survival depending on metastases number

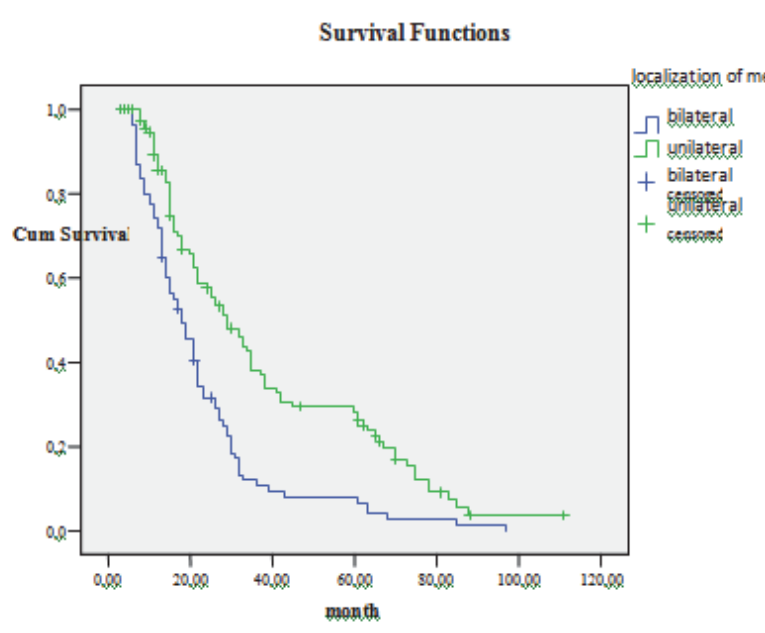

Fig. 8. Survival depending on localization of colorectal metastases

The statistical analysis of survival time showed that median survival was lowest in the group with left hemihepatectomy (about 14 months), and the highest in the group with resection of two segments (48 months). Statistical tests confirmed the difference in the length of survival among the types of liver resections as significant $(p=0.004, p=0.043)$, and type of resection in relation to the other factors in terms of survival as non-significant. Extent of resection was also not proved as a significant factor in terms of survival. The number of metastases was proved to be a significant predictor of survival in patients with colorectal cancer metastases of the liver. Patients with 2 to 4 metastases had a 1.5 times higher risk of fatal outcome compared to patients with one metastasis. Patients with more than 4 metastases had a twofold higher risk compared to patients with one metastasis. Statistical tests Log Rank and Breslow confirmed the difference in the length of survival time as significant $(p<0.0001)$. Patients with bilateral localization of liver metastases survived significantly shorter compared to patients with unilateral localization of metastases. 
Table 3. Cox-regression analysis on the relationship between laboratory parameters and survival of patients with colorectal metastases

\begin{tabular}{lccc}
\hline & $\mathbf{p}$ & $\operatorname{Exp}(\mathbf{B})$ & $\begin{array}{c}\mathbf{9 5 \%} \text { CI for } \\
\text { Exp (B) }\end{array}$ \\
\hline AST & 0.069 & 1.004 & $1.00-1.008$ \\
ALT & 0.894 & 1.00 & $0.996-1.004$ \\
GGT & 0.129 & 1.001 & $1.000-1.001$ \\
direct bilirubin & 0.266 & 1.027 & $0.98-1.007$ \\
total bilirubin & 0.737 & 0.995 & $0.969-1.023$ \\
PRT & 0.357 & 1.016 & $0.982-1.054$ \\
INR & 0.16 & 1.372 & $0.882-2.134$ \\
HGB & $0.007^{* *}$ & 0.989 & $0.981-0.995$ \\
CA 199 & 0.117 & 1.00 & $1.000-1.001$ \\
CEA & $0.008 * *$ & 1.001 & $1.000-1.002$ \\
AFP & 0.621 & 1.038 & $0.896-1.201$ \\
operative time & 0.631 & 0.999 & $0.997-1.002$ \\
blood loss & 0.084 & 1.001 & $1.000-1.001$ \\
\hline
\end{tabular}

Values of $\operatorname{Hgb}(p=0.007)$ and values of the tumor marker CEA $(p=0.008)$ were confirmed as significant predictors. The risk of a fatal outcome was reduced by $11 \%$ by increasing the HGB by 1 . Increasing tumor marker CEA 1 increased the risk of a fatal outcome by $0.1 \%$.

\section{Discussion}

The surgical resection represents the only curative treatment approach in patients with CRLM; in larger series the treated patients with resection have mean 5-year survival rate of $25 \%$ to $44 \%[15,20,21]$, but only 15 $25 \%$ [22] of liver metastases are initially resectable. Numerous publications indicate that gender and age do not significantly affect the survival of patients after resection of CRLM [23-25]. Many authors who compared synchronous with metachronous metastases, found superior results in favor of metachronous metastases [26-29], and others showed similar survival rates for both types of CRLM [30,31]. Tumor size of potentially resectible CRLM has been studied as a prognostic factor with contradictory results [32]. Ercolani et al. [33] demonstrated that the total tumor volume of liver metastases had a stronger impact on the survival compared to the number and location of metastases. In the multifactorial prognostic model described by Rees et al. [34] the number of CRLM $>3$ represents an independent prognostic factor for low rate of survival. Better survival of patients with four or more metastases was observed by Pawlik et al. [35], 5-year OS median survival of 50.9\%, and Kornprat et al. [36], 5-year survival of $33 \%$ OS. The prognostic significance of bilobar distribution of colorectal metastases became controversial. Some studies indicate the bilobar distribution as a poor prognostic factor, while others are reporting that it does not affect survival [37,38]. Tomlinson et al. [39] report five and ten percent survival OS of $29 \%$ and $25 \%$ with bilateral resection. Type of resection of the liver does not affect the survival of patients with CRLM. Non-anatomical resection is inferior compared to the anatomical resection regarding the marginal status, recurrent rate and survival [40]. Our study showed that the type of metastases, localization and inability to radical resection has a statistical significance in terms of survival. The type and extent of liver resection does not affect the survival, but the presence of metastases in the regional lymph glands, extrahepatic distant metastases, the elevated amount of CEA and stage IV disease have also significant effects on survival of patients after liver resection. Fong et al. [41] created a clinical risk score (CRS) using a regressive analysis of multiple clinical factors of patients resected due to colorectal liver metastases. They found five clinical criteria that have prognostic significance for survival: lymph node - initially positive, CEA $>200 \mathrm{ng} / \mathrm{ml},>1$ lesion liver, lesion $>5 \mathrm{~cm}$, DFI less than 1 year from the initial resection. They noticed that patients with CRS of 0,1 , 2 have a fondness for survival and surgical resection is a rational therapy. Patients with CRS 3, 4 and 5 have low survival and therefore surgical resection should be planned in the context of chemotherapy.

\section{Conclusion}

There are several ways for treatment of patients with colorectal liver metastases: radiofrequent ablation, transarterial chemoembolization, chemo-and radiotherapy as well as in selected cases liver transplantation, but only liver resection has curative sense. The surgical strategy for resection in context of increasing the percent of patients with resectable potential is the only possible factor for long-term survival.

\section{References}

1. Валерианова 3., Димитрова Н., Вуков М., Атанасов Т. Заболяемост от рак в България, 2015.

2. Ferlay J, Soerjomataram I, Ervik M, et al. GLOBOCAN 2012 v1.0, Cancer Incidence and Mortality Worldwide: IARC CancerBase No. 11 [online]. International Agency for Research on Cancer, Lyon (France) 2013.

3. Belghiti J, Hiramatsu K, Benoist S, et al. Seven hundred fourty-seven hepatectomies in the 1990s: an update to evaluate the actual risk of liver resection. J Am Coll Surg 2000; 191: 38-46.

4. Bismuth H, Houssin D, Mazmanian G. Postoperative liver insufficiency: prevention and management. World J Surg 1983; 7: 505-510.

5. Kandil E, Noureldine SI, Koffron A, et al. Outcomes of laparoscopic and open resection for neuroendocrine liver metastases. Surgery 2012; 152(6): 1225-1231.

6. Lai EC, Fan ST, Lo CM, et al. Anterior approach for difficult major right hepatectomy. World J Surg 1996; 20: 314-317.

7. Shaw IM, Rees M, Welsh FK, et al. Repeat hepatic resection for recurrent colorectal liver metastases is associated with favourable longterm survival. Br J Surg 2006; 93: 457-464.

8. Nordlinger B, Van Cutsem E, Rougier P, et al. Does chemotherapy prior to liver resection increase the potential for cure in patients with metastatic colorectal cancer? A report from the European Colorectal Metastases Treatment Group. Eur J Cancer 2007; 43(14): 2037-2045. 
9. Poston GJ, Figueras J, Giuliante F, et al. Urgent need for a new staging system in advanced colorectal cancer. J Clin Oncol 2008; 26: 4828-4833.

10. Van den Eynde M, Hendlisz A. Treatment of colorectal liver metastases: A review. Rev Recent Clin Trials 2009; 4: 56-62.

11. Altendorf-Hofmann A, Scheele J. A critical review of the major indicators of prognosis after resection of hepatic metastases from colorectal carcinoma. Surg Oncol Clin N Am 2003; 12: 165-192, xi.

12. Benjamin IS, Blumgart LH. Occult hepatic metastases in colorectal carcinoma. Br J Surg 1986; 73: 1046.

13. Jatzko G, Wette V, Muller M, et al. Simultaneous resection of colorectal carcinoma and synchronous liver metastases in a district hospital. Int J Colorectal Dis 1991; 6: 111-114.

14. Pawlik TM, Choti MA. Surgical therapy for colorectal metastases to the liver. J Gastrointest Surg 2007; 11: 1057-1077.

15. Scheele J, Stang R, Altendorf-Hofmann A, et al. Resection of colorectal liver metastases. World J Surg 1995; 19: 59-71.

16. Chen TW, Chu CM, Yu JC, et al. Comparison of clinical staging systems in predicting survival of hepatocellular carcinoma patients receiving major or minor hepatectomy. Eur J Surg Oncol 2007; 33: 480-487.

17. de Haas RJ, Adam R, Wicherts DA, et al. Comparison of simultaneous or delayed liver surgery for limited synchronous colorectal metastases. Br J Surg 2010; 97: 12791289 [PMID: 20578183 DOI: 10.1002/bjs. 7106.

18. Masi G, Loupakis F, Pollina L, et al. Long-term outcome of initially unresectable metastatic colorectal cancer patients treated with 5-fluorouracil/leucovorin, oxaliplatin, and irinotecan (FOLFOXIRI) followed by radical surgery of metastases. Ann Surg 2009; 249: 420-425

19. Mathur AK, Ghaferi AA, Osborne NH, et al. Body mass index and adverse perioperative outcomes following hepatic resection. J Gastrointest Surg 2010; 14: 1285-1291 [PMID: 20532666 DOI:10.1007/s11605-010-1232-9].

20. Cescon M, Vetrone G, Grazi GL, et al. Trends in perioperative outcome after hepatic resection: analysis of 1500 consecutive unselected cases over 20 years. Ann Surg 2009; 249: 9951002[PMID: 19474679DOI: 10.1097/SLA.0b013e3181a63c74].

21. Fong Y, Fortner J, Sun RL, et al. Clinical score for predicting recurrence after hepatic resection for metastatic colorectal cancer: analysis of 1001 consecutive cases. Ann Surg 1999; 230: 309-318.

22. McKay A, You I, Bigam D, et al. Impact of surgeon training on outcomes after resective hepatic surgery. Ann Surg Oncol 2008; 15: 1348-1355 [PMID: 18306973 DOI: 10.1245/s10434-008-9838-9].

23. Jenkins LT, Millikan KW, Bines SD, et al. Hepatic resection for metastatic colorectal cancer. Am Surg 1997; 63: 605-610.

24. Lise M, Bacchetti S, Da Pan P, et al. Patterns of recurrence after resection of colorectal liver metastases: prediction by models of outcome analysis. World J Surg 2001; 25: 638-644.

25. Minagawa M, Makuuchi M, Torzilli G, et al. Extension of the frontiers of surgical indications in the treatment of liver metastases from colorectal cancer: long-term results of our experience. Ann Surg 2000; 23: 487-499.
26. Nordlinger B, Guiguet M, Vaillant JC, et al. Surgical resection of colorectal carcinoma metastases to the liver. A prognostic scoring system to improve case selection, based on 1568 patients. Association Francaise de Chirurgie. Cancer 1996; 77: 1254-1262.

27. Pawlik TM, Scoggins CR, Zorzi D, et al. Effect of surgical margin status on survival and site of recurrence after hepatic resection for colorectal metastases. Ann Surg 2005; 241: 715-722.

28. Riesener KP, Kasperk R, Winkeltau G, Schumpelick V. Repeat resection of recurrent hepatic metastases-improvement in prognosis? Eur J Surg 1996; 162: 709-715.

29. Shaw IM, Rees M, Welsh FK, et al. Repeat hepatic resection for recurrent colorectal liver metastases is associated with favourable longterm survival. Br J Surg 2006; 93: 457-464.

30. Aramaki M, Kawano K, Kai T, et al. Postoperative complications of repeat hepatectomy for liver metastasis from colorectal carcinoma. Hepatogastroenterology 2000; 47: 478-480.

31. Jakab F, Mersich T. Repeat resection of the liver-a challenge in modern oncologic surgery. Magy Seb (2010) 63: 3-8.

32. Pawlik TM, Schulick RD, Choti MA. Expanding criteria for resectability of colorectal liver metastases. Oncologist 2008; 13: 51-64.

33. Ercolani G, Grazi GL, Ravaioli M, et al. Liver resection for multiple colorectal metastases: influence of parenchymal involvement and total tumor volume, vs number or location, on long-term survival. Arch Surg 2002; 137(10): 1187-1192.

34. Rees M, Tekkis PP, Welsh FK, et al. Evaluation of longterm survival after hepatic resection for metastatic colorectal cancer: a multifactorial model of 929 patients. Ann Surg 2008; 247: 125-135.

35. Pawlik TM, Abdalla EK, Ellis LM, et al. Debunking dogma: surgery for four or more colorectal liver metastases is justified. J Gastrointest Surg 2006; 10: 240-248.

36. Kornprat $\mathrm{P}$, Jarnagin WR, Gonen $\mathrm{M}$, et al. Outcome after hepatectomy for multiple (four or more) colorectal metastases in the era of effective chemotherapy. Ann Surg Oncol 2007; 14: 1151-1160.

37. Попов, В. Прогноза на далечната преживяемост чрез определяне стадия на чернодробните метастази/V. Popov. // Lekarska praktika, 7, 2005; N 6, c. 9-11.

38. Jaeck D, Pessaux P. Bilobar colorectal liver metastases: treatment options. Surg Oncol Clin N Am 2008; 17: 553-568.

39. Tomlinson JS, Jarnagin WR, DeMatteo RP, et al. Actual 10-year survival after resection of colorectal liver metastases defines cure. J Clin Oncol 2007; 25: 4575-4580.

40. Sarpel U, Bonavia AS, Grucela A, et al. Does anatomic versus nonanatomic resection affect recurrence and survival in patients undergoing surgery for colorectal liver metastasis? Ann Surg Oncol 2009; 16: 379-384.

41. Fong Y, Fortner J, Sun RL, et al. Clinical score for predicting recurrence after hepatic resection for metastatic colorectal cancer: analysis of 1001 consecutive cases. Ann Surg 1999; 230: 309-318. discussion 318-321. 